\title{
Comparison of mineral and trace element contents between organically and conventionally grown fruit
}

\author{
Pollyanna C. Cardoso Pires ${ }^{1, \star}$, Flávia G. Cândido ${ }^{2}$, Leandro M. Cardoso ${ }^{2}$, Neuza M.B. Costa $^{3}$, \\ Hércia S.D. Martino ${ }^{2}$ and Helena M. Pinheiro-Sant' Ana ${ }^{2}$ \\ 1 Department of Nutrition, Federal University of Juiz de Fora, Governador Valadares Campus, 35010-177, Governador Valadares, Minas \\ Gerais, Brazil \\ 2 Department of Nutrition and Health, Federal University of Viçosa, Campus Universitário, 36571-000, Viçosa, Minas Gerais, Brazil \\ 3 Department of Pharmacy and Nutrition, Federal University of Espírito Santo, Alto University, 29500-000, Alegre, Espírito Santo, Brazil
}

Received 23 June 2014 - Accepted 2 October 2014

\begin{abstract}
Introduction. Many consumers buy organic foods because of their alleged greater nutritional benefits. However, studies investigating the effect of the agricultural farming system on minerals and toxic elements content are scarce. This study compared the content of minerals ( $\mathrm{P}, \mathrm{Ca}, \mathrm{Mg}, \mathrm{Na}$ and $\mathrm{K}$ ) and trace elements $(\mathrm{Fe}, \mathrm{Mn}, \mathrm{Cu}, \mathrm{Cr}, \mathrm{Se}$, $\mathrm{Zn}, \mathrm{Mo}, \mathrm{Ni}, \mathrm{Cd}$ and $\mathrm{Al}$ ) of four organically and conventionally grown fruits in Brazil. Materials and methods. Mango (Mangifera indica L., var. Palmer), persimmon (Diospyros kaki L., var. Rama Forte), acerola (Malpighia punicifolia L., var. Olivier) and strawberry (Fragaria vesca L., var. Oso Grande) were produced by organic and conventional farming in the same geographic region, under the same climatic conditions and same type of soil. Mineral analysis was performed by inductively coupled plasma atomic emission spectrometry (ICP-AES). Results and discussion. Organic mango contained higher amounts of $\mathrm{Mg}$ and $\mathrm{K}$, and $\mathrm{Cr}$ content was higher in conventionally grown mangos. Organic persimmon contained higher amounts of $\mathrm{Cu}$ and $\mathrm{Zn}$, and $\mathrm{Mg}, \mathrm{P}, \mathrm{Na}$, and $\mathrm{K}$ concentration was higher in conventional persimmon. Conventionally grown acerola contained higher amounts of $\mathrm{Ca}, \mathrm{Fe}, \mathrm{Mn}, \mathrm{Mo}, \mathrm{Al}$, and Ni than the organic acerola. The concentrations of Mo and Al were higher in organic strawberry when compared to conventional strawberry. Conclusion. Organic farming did not result in a clear superiority of the mineral quality of fruit nor did it provide fruit free of toxic elements.
\end{abstract}

Keywords: Brazil / mango / persimmon / acerola / strawberry / organic farming / conventional farming / micronutrients / toxic minerals

Résumé - Comparaison de la composition en minéraux et oligoéléments de fruits produits par agriculture biologique et conventionnelle. Introduction. Nombreux sont les consommateurs qui achètent des aliments biologiques en raison des allégations sur leurs bénéfices nutritionnels présumés. Cependant, les études portant sur l'effet du système de culture sur le contenu en minéraux et éléments toxiques sont rares. Notre étude a comparé la composition en minéraux $(\mathrm{P}, \mathrm{Ca}, \mathrm{Mg}, \mathrm{Na}$ et $\mathrm{K}$ ) et oligoéléments ( $\mathrm{Fe}, \mathrm{Mn}, \mathrm{Cu}, \mathrm{Cr}, \mathrm{Se}, \mathrm{Zn}, \mathrm{Mo}, \mathrm{Ni}, \mathrm{Cd}$ et $\mathrm{Al}$ ) de quatre fruits produits au Brésil à partir d'agriculture biologique et conventionnelle. Matériel et méthodes. Mangues (Mangifera indica L., var. Palmer), kakis (Diospyros kaki L., var. Rama Fort), acerola (Malpighia punicifolia L., var. Olivier) et fraises (Fragaria vesca L., var. Oso Grande) ont été produits par culture biologique ou conventionnelle dans la même région géographique, dans les mêmes conditions climatiques et le même type de sol. L'analyse minérale a été conduite par spectrométrie d'émission atomique (ICP-AES). Résultats et discussion. Les mangues biologiques contenaient des quantités plus élevées de $\mathrm{Mg}$ et $\mathrm{K}$ et la teneur en $\mathrm{Cr}$ était plus forte pour les mangues conventionnelles. Les kakis biologiques contenaient des quantités plus importantes de $\mathrm{Cu}$ et $\mathrm{Zn}$ alors que les teneurs en $\mathrm{Mg}, \mathrm{P}, \mathrm{Na}$ et $\mathrm{K}$ étaient plus fortes pour les kakis conventionnels. L'acerola conventionnel contenait des quantités plus élevées de Ca, Fe, Mn, Mo, Al et Ni que l'acerola biologique. Les concentrations en Mo et $\mathrm{Al}$ étaient plus fortes dans les fraises biologiques que dans les fraises conventionnelles. Conclusion. Si le système de culture biologique n'a pas impliqué une nette supériorité de la qualité minérale des fruits, il n'a pas non plus fourni des fruits exempts d'éléments toxiques.

Mots clés : Brésil / mangue / kaki / acerola / fraise / agriculture biologique / agriculture conventionnelle / micronutriments / minéraux toxiques

^ Corresponding author: pollyanna.cardoso@ufjf.edu.br 


\section{Introduction}

Organic agriculture is promoted and widely accepted as a holistic sustainable production system that favors environmental preservation, agro-biodiversity and biological cycles, maintains and increases soil fertility, minimizes pollution, and restricts the use of chemical fertilizers and pesticides. In addition, organic farming has social and economic repercussions since it is intended to produce high-quality foods in sufficient quantity $[1,2]$.

Many consumers buy organic foods because of their alleged greater nutritional benefits [1], lower content of environmental contaminants [3], and lower risks to human health [1]. However, few studies regarding the nutrient content of organically and conventionally grown fruits are available in the literature and only a small number of fruits produced by these two farming systems have been analyzed, a fact demonstrating the need for investment and concern on the part of research institutions and the federal government in this area. Furthermore, current evidence does not support any meaningful nutritional benefits or deficits from eating organic compared with conventionally grown foods, and there are no rigorous human studies that directly demonstrate health benefits or disease protection as a result of consuming an organic diet. Data are both scarce and inconsistent with respect to demonstrating such advantages [3,4]. Magkos et al. [5] suggest caution in drawing general conclusions due to the lack of adequate comparative data for the two farming systems.

Brazil is one of the largest producers of organic fruit and has shown marked growth over the past few years [6]. Fruit production is encouraged in tropical countries because these foods are good sources of nutrients [7]. Increased consumption of fruit increases the intake of micronutrients that participate in vital physiological and biochemical activities known to be essential for the maintenance of human health [7-9]. Diets high in fruit and vegetables are associated with a lower risk of coronary diseases, diabetes and cancer due to the presence of micronutrients, fibers and phytochemicals [10], and with the prevention of diseases related to micronutrient deficiency. Thus, the consumption of fruits and vegetables should be encouraged.

However, fruits may contain significant amounts of toxic elements or heavy metals as a result of atmospheric deposition, urban-industrial activities and agronomic practices. The last factor is the main source of heavy metals in agricultural soils $[9,11]$. These elements accumulate in the organism and can have deleterious effects on human health such as high blood pressure and cardiovascular diseases, liver disease, neurological alterations, renal failure, and immunological and endocrine disorders in addition to having teratogenic, mutagenic and carcinogenic effects [9].

There is growing interest in the mineral content of foods and diets. The concentration of minerals and toxic elements in fruit is known to be variable and is influenced by the species and cultivar, climatic conditions, geological origin of the soil, use of fertilizers and other agricultural chemicals, plant growth stage, and availability of soil elements [8].

Studies investigating the effect of the farming system on minerals and toxic elements content are uncommon but are important to predict the possible benefits or risks to human health from consuming organic or conventional foods [5]. Within this context, the objective of the present study was to analyze the minerals ( $\mathrm{P}, \mathrm{Ca}, \mathrm{Mg}, \mathrm{Na}$ and $\mathrm{K}$ ) and trace elements ( $\mathrm{Fe}, \mathrm{Mn}, \mathrm{Cu}, \mathrm{Cr}, \mathrm{Se}, \mathrm{Zn}, \mathrm{Mo}, \mathrm{Ni}, \mathrm{Cd}$ and $\mathrm{Al}$ ) content of four fruits commonly produced and consumed in Brazil, comparing organic and conventional farming systems.

\section{Materials and methods}

\subsection{Reagents}

Nitric acid (65\% analytical grade) was used for the analysis of minerals and trace elements in the samples. Deionized water was produced with a Lab-UPW 483 deionizer (TKA Wasseraufbereitungssysteme GmbH, Darmstadt, Germany). Standards of the chemical elements were purchased from Vetec (Rio de Janeiro, Brazil) and Merck (Darmstadt, Germany).

\subsection{Fruits and experimental design}

Mango (Mangifera indica L., var. Palmer), persimmon (Diospyros kaki L., var. Rama Forte), acerola (Malpighia punicifolia L., var. Olivier), and strawberry (Fragaria vesca L., var. Oso Grande) were obtained from the Brazilian company Kórin Agricultura Natural Ltda, Atibaia, São Paulo. These fruits were produced by organic and conventional farming in the same geographic region, under the same climatic conditions and same type of soil. The distance between the farms of organic and conventional production was $2890 \mathrm{~m}$ for mango, $6920 \mathrm{~m}$ for persimmon, $7880 \mathrm{~m}$ for acerola, and $4980 \mathrm{~m}$ for strawberry. The conditions adopted for the cultivation of these fruit crops were as follows:

1) Conventional farming: the soil was fertilized with $40 \mathrm{~kg} \mathrm{ha}^{-1} \mathrm{~N}, 600 \mathrm{~kg} \mathrm{ha}^{-1} \mathrm{P}, 240 \mathrm{~kg} \mathrm{ha}^{-1} \mathrm{~K}$. During the growing season, $30 \mathrm{~kg} \mathrm{ha}^{-1} \mathrm{~N}$ and $15 \mathrm{~kg} \mathrm{ha}^{-1} \mathrm{~K}$ were applied to the soil and as foliar sprays. The control of pests and diseases was done using appropriate pesticides;

2) Organic farming: soil nutrients were not corrected using chemical fertilizer. Millet was planted three months before planting organic fruit trees and was used as green manure. Fifteen days before planting, the soil was fertilized with $100 \mathrm{~g} \mathrm{~m}^{-2}$ of "Bokashi", composed of rice bran, castor seed meal, feather and viscera meal, rice hulls and molasses. During cultivation, disease control was performed using Viçosa syrup obtained from a mixture of Bordeaux syrup (copper sulphate and hydrated lime to neutralize the slurry) and micronutrients (zinc sulfate, magnesium sulfate, and boron). Insect control involved the use of compatible companion plants.

In both systems, water was applied using drip irrigation. Organic fruits were certified by the certifying agency Certificadora Motika Okada. The samples for analysis were randomly selected during the harvest period of each crop. 
Fruits judged to be commercially mature were harvested, stored in rigid cardboard boxes for protection against bruising, and transported to the Laboratory of Vitamin Analysis, Universidade Federal de Viçosa, within $48 \mathrm{~h}$ harvest. In the laboratory the fruits were selected using the following criteria: mango - soft fruit when lightly pressed with fingers, skin $75 \%$ purplish-red, flesh yellow; persimmon - firm fruit with $90 \%$ red skin color; acerola - firm fruit with $95 \%$ red skin color; strawberry - firm fruit with $80 \%$ red external color.

A completely randomized design consisting of 2 treatments (organic and conventional farming system), 3 repetitions per treatment, and duplicate analysis of the samples was used. The Student $t$-test ( $\alpha=5 \%$ ) was used for mean separation using the Statistical Analysis System (SAS) package, version 9.1, licensed to Universidade Federal de Viçosa.

\subsection{Collection, sampling and sample preparation}

The organic and conventional fruits were collected in such a way to obtain three different repetitions, i.e., the production area was divided into three plots and fruits were collected from each plot. In each plot, $2 \mathrm{~kg}$ mango and persimmon, and $1 \mathrm{~kg}$ acerola and strawberry produced by organic and conventional farming were collected.

The fruits were washed under running water and the nonedible parts were removed (mango: skin and seed; persimmon: calyx; acerola: seed; strawberry: stem). One kg organic and conventional mango and persimmon, and $500 \mathrm{~g}$ organic and conventional acerola and strawberry were respectively chopped and homogenized in a blender for $5 \mathrm{~min}$ to obtain the pulp. Next, approximately $200 \mathrm{~g}$ of each pulp sample was stored in a freezer at $-70{ }^{\circ} \mathrm{C}$. The samples were then lyophilized in a lyophilizer (model Fauvel LH 0400, Terroni, São Paulo, Brazil) at $-1{ }^{\circ} \mathrm{C}$ under vacuum for approximately $20 \mathrm{~h}$ for the concentration of total solids, wrapped in properly identified and sealed plastic bags, and stored at $-18{ }^{\circ} \mathrm{C}$ until the time for preparation of the mineral solution.

\subsection{Acid digestion of the samples}

Acid digestion was performed as previously described [8] with some modifications. About $1 \mathrm{~g}$ of lyophilized sample was transferred to a $100 \mathrm{~mL}$ digestion tube in duplicate for each repetition and $10 \mathrm{~mL}$ nitric acid was added. The mixture was kept at room temperature for approximately $24 \mathrm{~h}$. The tubes were placed in a digestion block with a capacity of 40 tubes equipped with a thermostat (model TE 040/25, Tecnal, São Paulo, Brazil) for hot acid digestion. The tubes were heated to $50{ }^{\circ} \mathrm{C}$ and the temperature was then gradually increased to $80^{\circ} \mathrm{C}$ until orange color vapor was no longer arising from the samples. After $6 \mathrm{~h}$ of digestion an additional $5 \mathrm{~mL}$ nitric acid was added. The temperature was then gradually increased to $120{ }^{\circ} \mathrm{C}$ and digestion was completed after a period of 16 to $20 \mathrm{~h}$ until the solution was clear or colorless and whitish smoke arose from the tubes. The tubes were cooled to room temperature and the digested solution was transferred to a $25 \mathrm{~mL}$ volumetric flask, completed with deionized water and vortexed.
The mineral solution was stored in a stoppered plastic bottle until the time of element analysis. Three tubes without samples (blanks) were prepared under the same conditions as described above.

All materials and glassware used for element analysis were properly demineralized.

\subsection{Determination of minerals and trace elements}

Minerals and trace elements content was analyzed by inductively coupled plasma atomic emission spectrometry (model Optima 3300 DV, Perkin Elmer, Massachusetts, USA) with an inducible plasma argon source. Analysis was performed under the following conditions: power of $1,300 \mathrm{~W}$, plasma argon flow rate of $15 \mathrm{~L} \mathrm{~min}^{-1}$, auxiliary argon flow rate of $0.7 \mathrm{~L} \mathrm{~min}^{-1}$, nebulizer argon flow rate of $0.5 \mathrm{~L} \mathrm{~min}^{-1}$,

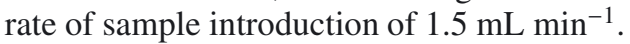

The elements were quantified in the samples against an external standard consisting of multi-element standard solutions. The analytical curves were obtained using six different concentrations. The maximum concentration of the elements in the multi-element standard solutions and the wavelengths (nm) selected for analysis of the samples are presented in table I. After the readings, the element concentration in the samples was calculated taking into account the dilution and possible presence of elements in the blank sample and is expressed as ppm $\left(\mathrm{mg} \mathrm{L}^{-1}\right)$.

The limit of detection (LOD) and limit of quantification (LOQ) for each element evaluated were determined based on the IUPAC recommendation:

$$
\mathrm{LOD}=(3 \mathrm{~s}) / \mathrm{S} \text { and } \mathrm{LOQ}=(10 \mathrm{~s}) / \mathrm{S}
$$

where $\mathrm{s}$ is the relative standard deviation of the measurements of a blank solution and $\mathrm{S}$ represents the slope of the analytical curve used for quantification [12].

\section{Results and discussion}

The mean minerals and trace elements content of the organically and conventionally produced fruit samples is shown in table II.

For mango, significant differences $(P<0.05)$ between the two farming systems were only observed for $\mathrm{Mg}, \mathrm{K}$ and $\mathrm{Cr}$, with a higher $\mathrm{Mg}$ and $\mathrm{K}$ content in organic mango and a higher $\mathrm{Cr}$ content in conventional mango. The latter finding might be explained by the use of chemical fertilizers containing $\mathrm{Cr}$ [13].

The concentration of $\mathrm{Mg}, \mathrm{Cu}, \mathrm{Zn}, \mathrm{P}, \mathrm{Na}$ and $\mathrm{K}$ in persimmon differed $(P<0.05)$ between farming systems, with a higher $\mathrm{Mg}, \mathrm{P}, \mathrm{Na}$ and $\mathrm{K}$ content in conventionally grown persimmon and a higher $\mathrm{Cu}$ and $\mathrm{Zn}$ content in organic fruits. Copper and zinc sulfate were added to the organic plantation, a fact that might explain the higher concentration of these elements in organic persimmon.

Conventional acerola contained higher amounts of $\mathrm{Ca}, \mathrm{Fe}$, $\mathrm{Mn}$ and Mo than organic acerola $(P<0.05)$. Studies investigating the association between mineral fertilization of acerola 
Table I. Concentration maximum of elements in standard solution, wavelengths for analysis, $\mathrm{LOD}^{\mathrm{a}}$ and $\mathrm{LOQ}^{\mathrm{b}}$.

\begin{tabular}{lcccc}
\hline Element & $\begin{array}{c}\text { Concentration maximum in } \\
\text { standard solution }\left(\mathrm{mg} \mathrm{L}^{-1}\right)\end{array}$ & Wavelengths $(\mathrm{nm})$ & LOD $\left(\mu \mathrm{g} \mathrm{L}^{-1}\right)$ & LOQ $\left(\mu \mathrm{g} \mathrm{L}^{-1}\right)$ \\
\hline $\mathrm{Ca}$ & 80.0 & 318 & 0.02 & 0.20 \\
$\mathrm{Fe}$ & 2.0 & 260 & 2.0 & 20.0 \\
$\mathrm{Mg}$ & 80.0 & 285 & 0.1 & 1.0 \\
$\mathrm{Mn}$ & 2.0 & 259 & 0.4 & 4.0 \\
$\mathrm{Cu}$ & 1.0 & 225 & 0.4 & 4.0 \\
$\mathrm{Zn}$ & 1.0 & 214 & 1.0 & 10.0 \\
$\mathrm{Se}$ & 0.5 & 196 & 50.0 & 500.0 \\
$\mathrm{Mo}$ & 0.5 & 202 & 3.0 & 30.0 \\
$\mathrm{Cr}$ & 0.5 & 268 & 2.0 & 20.0 \\
$\mathrm{P}$ & 39.0 & 214 & 30.0 & 300.0 \\
$\mathrm{~K}$ & 100.0 & 405 & 20.0 & 200.0 \\
$\mathrm{Na}$ & 20.0 & 590 & 3.0 & 30.0 \\
$\mathrm{Cd}$ & 1.0 & 214 & 1.0 & 10.0 \\
$\mathrm{Al}$ & 1.0 & 308 & 3.0 & 30.0 \\
$\mathrm{Ni}$ & 1.0 & 232 & 6.0 & 60.0 \\
\hline
\end{tabular}

${ }^{a}$ LOD: Limit of detection; ${ }^{b}$ LOQ: Limit of quantification.

plants and the nutritional value of its fruit are scarce. According to Corrêa et al. [14], phosphate fertilization of acerola plants is a common practice and the addition of zinc to these fertilizer formulas has been recommended, particularly in regions where this element is deficient. The interaction between $\mathrm{P}$ and $\mathrm{Zn}$ positively affects the accumulation of $\mathrm{Ca}, \mathrm{Cu}, \mathrm{Fe}$ and $\mathrm{Mn}$ in the leaves of the plant and probably in the fruits. In addition, the higher $\mathrm{Ca}$ concentration found in conventionally grown acerola might be due to the soil application of chemical fertilizers containing this nutrient in their formulation [14], or to the liming process. The higher Mo content might be explained by the use of micronutrient fertilizers containing this element and others such as Fe and Mn for conventional farming [13]. According to He et al. [11], the higher Fe and Mn content observed in conventional plantations may also be due to the application of fungicides, pesticides and herbicides.

For strawberry only Mo content differed significant $(P<$ 0.05 ) between the two farming systems, with higher amounts of this element being observed in organic strawberry. These results agree with Hakala et al. [15] who found no significant differences in $\mathrm{Mn}, \mathrm{Mg}, \mathrm{Ca}, \mathrm{K}, \mathrm{Fe}, \mathrm{Zn}$ and $\mathrm{Cu}$ concentrations between three strawberry varieties produced organically and conventionally.

With respect to agronomic practices, Welch and Graham [13] demonstrated the use of agricultural techniques to increase the productivity of cultivars and their micronutrient quality to meet human needs. The application type, frequency and quantity of chemical fertilizers affect the mineral content of cultivars. The authors highlighted the type and quantity of fertilizers containing macronutrients (e.g., $\mathrm{N}, \mathrm{P}, \mathrm{K}, \mathrm{Mg}, \mathrm{Ca}$, and $\mathrm{S}$ ) that affect protein, lipid, vitamin and antinutrient levels, and the type, application method and quantity of micronutrient fertilizers which are effective for $\mathrm{Zn}$, $\mathrm{Mo}, \mathrm{Ni}, \mathrm{Se}, \mathrm{Cl}$, Li, but present limited effectiveness for $\mathrm{Fe}$, $\mathrm{Cu}, \mathrm{Mn}, \mathrm{B}, \mathrm{Cr}$, and $\mathrm{V}$. In addition, fungicides, pesticides and herbicides may contain $\mathrm{Cu}, \mathrm{Zn}, \mathrm{Fe}, \mathrm{Mn}$, and $\mathrm{As}$ [11].
The process of micronutrient accumulation in soil is not completely understood, with the complexity and volume of literature data making this understanding difficult [13]. However, nutrient availability is known to be related to soil fertility. This study was not designed to evaluate the fertility of the soils in which the fruits were grown, but the results obtained might be related to soil condition. According to Bataglia [16], the Diagnosis and Recommendation Integrated System can be used to classify the degree of nutrient limitation and to calculate the nutritional balance for the plant studied. The author showed that $60 \%$ of cultivated soils are affected by nutrient limitations or toxicity, and $50 \%$ of the human population may suffer one or more micronutrient deficiencies.

Clark et al. [17] showed that soil supply of C, P, K, Ca and $\mathrm{Mg}$ was higher in organic farming systems as a result of the type of fertilization and cultivation practices. However, Mäder et al. [18] reported lower soil supply of $\mathrm{N}, \mathrm{P}$ and $\mathrm{K}$ in organic systems compared to conventional farming.

The nutrient composition of organic products does not significantly differ from that of conventional foods [3]. An increased micronutrient content of organic foods was reported in some studies, but this small difference does not seem to have implications for consumer health, in agreement with the present study [3]. The significant differences between farming systems found for each fruit do not have marked physiological implications since the mineral content of fruits is low when considering nutritional requirements.

Considering the average of the recommendations of minerals and trace elements for adult women and men aged between 19 and 30 years [19-22], assuming the consumption of a serving of $100 \mathrm{~g}$ of pulp, and respecting the recommendations of the National Sanitary Surveillance Agency (ANVISA; Decree No. 27 from January 13, 1998), solid foods ready for consumption are classified as a "source" when they meet $15 \%$ of the dietary reference intake (DRI) [23]. In this study we found that the analyzed fruits were source of Se. Organic and conventional mango delivered $29.1 \%$ and $23.6 \%$ of the DRI for this 


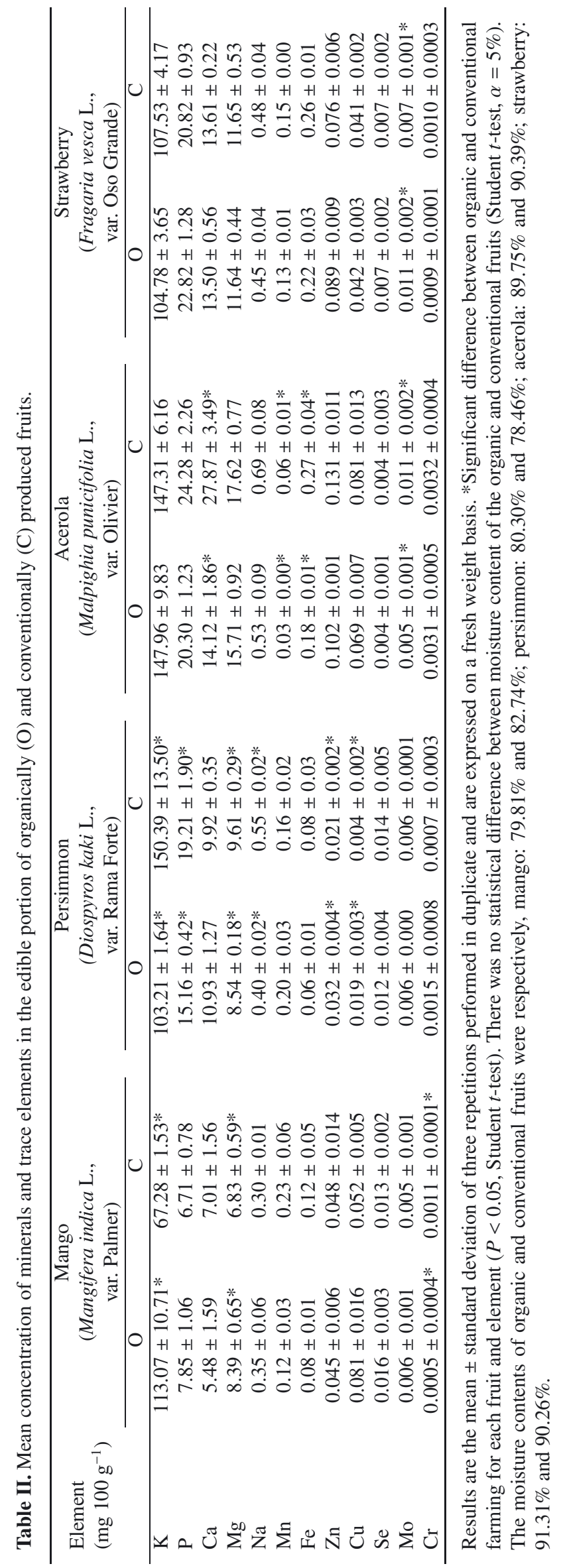




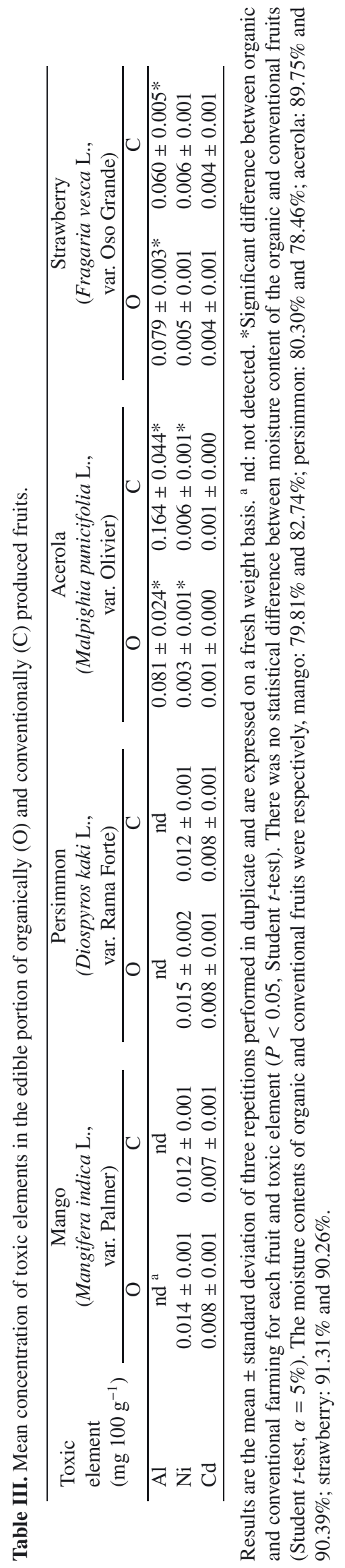


minerals and organic persimmon and conventional persimmon supplied $21.8 \%$ and $25.5 \%$, respectively. For Mo, conventional acerola delivered $24.4 \%$, organic strawberry $24.4 \%$ and conventional strawberry $15.6 \%$.

The use of pesticides reduces the ability of cultivars to incorporate soil minerals and to transport them to different parts of the plant, as well as nutrient synthesis by the plant itself [24]. Trewavas [25] reported that the mineral composition of conventional foods may vary substantially depending on growth conditions and on the use of fertilizers.

Comparisons between farming systems should be experimentally validated using a representative sample and an adequate analysis method, which has often not been applied in studies [26]. In addition, factors such as the type of variety, cultivation management, and harvest and post-harvest practices need to be controlled. Caris-Veyrat et al. [27] emphasized that organic and non-organic products should be obtained under the same cultivation conditions (geographic region and climatic condition). As a consequence, the results of many studies on organically and conventionally grown foods are contradictory, in addition to the scarcity of investigations in this area, especially in the branch of fruit culture, thus impairing the comparison of nutritional quality between these foods.

The toxic trace elements $\mathrm{Al}, \mathrm{Cd}$ and $\mathrm{Ni}$ were found in organic and conventional fruits, except for $\mathrm{Al}$ which was not detected in mango and persimmon. For mango, no difference in the concentrations of toxic elements was observed between farming systems. Significantly higher amounts of $\mathrm{Al}$ and $\mathrm{Ni}$ were observed in conventionally grown acerola $(P<0.05)$. For strawberry, $\mathrm{Al}$ concentration was higher in organic fruit $(P<0.05)$ (table III).

With respect to toxicity on human health, the organic and conventional fruits analyzed in this study contained low concentrations of toxic elements and presented no risk to consumers. According to ANVISA [28], the upper limit of tolerance of inorganic contaminants in fruits is 0.1 and $0.5 \mathrm{mg}$ $100 \mathrm{~g}^{-1}$ for $\mathrm{Cd}$ and $\mathrm{Ni}$, respectively. In addition, dietary intake of Al should not exceed $6 \mathrm{mg} \mathrm{day}^{-1}$ [29].

Although Pussemier et al. have reported a lower quantity of pesticide residues in organic products compared to conventionally grown products [26], generalized environmental contamination and chemical products leaking from conventional farms may negatively affect organic farming areas. As a consequence, a reduction in agrochemical use is not sufficient to guarantee the absence of contamination of cultivars with heavy metals [30].

Furthermore, since contaminants may originate from packaging material used for the storage of these foods, both organic and conventional products are subject to contamination from plastic and recycled materials. Aluminum and polyvinyl chloride $(\mathrm{PVC})$ materials are prohibited for organic products but recycled packages are permitted, a fact that may lead to contamination with some heavy metals [26].

The use of fertilizers may contaminate soil with $\mathrm{Cd}$ and $\mathrm{Pb}$ [11]. In this respect, phosphate fertilizers are the main source of heavy metals among all mineral fertilizers. The application of fertilizers can increase the bioavailability of heavy metals in soil due to the chemical alterations provoked by their use. Thus, the type and quantity of chemical fertilizer used is an important route for heavy metals to enter the food chain. In Brazil, regulations determine the allowable upper limit of toxic heavy metals in mineral fertilizers containing phosphorus $\left(0.75 \mathrm{Cd}\right.$ in $\mathrm{m} \mathrm{kg}^{-1}$ per percentage point of $\left.\mathrm{P}_{2} \mathrm{O}_{5}\right)$ and in fertilizers that exclusively contain micronutrients $(15 \mathrm{Cd}$ and $420 \mathrm{Ni}$, in $\mathrm{mg} \mathrm{kg}^{-1}$ per percentage point of micronutrient) [31].

The use of fertilizers and pest control chemicals, urbanindustrial activities, and the type of irrigation and fertilization can influence the accumulation of trace elements in soils [11]. Heavy metals and dioxins, important chemicals found in the environment especially in industrialized areas, can contaminate both organically and conventionally produced foods [26], as can contaminated water used for irrigation [11].

\section{Conclusion}

Organic farming did not result in a clear superiority of the mineral quality of fruits, nor did it provide fruits free of toxic elements. The organically and conventionally produced fruits analyzed in this study (Mangifera indica L., var. Palmer; Diospyros kaki L., var. Rama Forte; Malpighia punicifolia L., var. Olivier; and Fragaria vesca L., var. Oso Grande) contained low concentrations of toxic elements that presented no risk to consumer health. However, attention should be paid to the possible environmental and human health implications of irresponsible conventional farming practices.

Further studies are necessary to gain more clarity on the effects of farming systems on the mineral and toxic element contents of fruit. These elements can have a positive or negative effects on human health and the environment. Studies like the present one are important to complement food composition databases.

Acknowledgements. The authors thank the Brazilian funding agency $\mathrm{CNPq}$ for financial support and for granting Master's and scientific initiation fellowships, and the state funding agency FAPEMIG for granting a scientific initiation fellowship.

\section{References}

[1] Winter C.K., Davis S.F., Organic foods, J. Food Sci. 71 (2006) R117-R124.

[2] Lester G.E., Manthey J.A., Buslig B.S., Organic vs conventionally grown Rio Red whole grapefruit and juice: comparison of production inputs, market quality, consumer acceptance, and human health-bioactive compounds. J Agric. Food Chem. 55 (2007) 4474-4480.

[3] Forman J., Silverstein J., Organic foods: health and environmental advantages and disadvantages, Pediatrics 130 (2012) e1406e1415.

[4] Lester G.E., Saftner R.A., Organically versus conventionally grown produce: common production inputs, nutritional quality, and nitrogen delivery between the two systems, J. Agric. Food Chem. 59 (2011) 10401-10406.

[5] Magkos F., Arvaniti F., Zampelas A., Organic food: buying more safety or just peace of mind? A critical review of the literature, Crit. Rev. Food Sci. Nutr. 46 (2006) 23-56. 
[6] Borges A., Fancelli M., Ritzinger C., Reinhardt D., Silva M.d., Trindade A., Souza L.d.S., Stringheta P., Muniz J., Aspectos gerais da produção orgânica de frutas. Alimentos orgânicos: produção, tecnologia e certificação, in: Stringheta, P.C., Muniz, N. (Eds), Aliments orgânicos: produção, techologia, ecertifição, Viçosa, MG, UFV (2003) 235-288.

[7] Leterme P., Buldgen A., Estrada F., Londoño A.M., Mineral content of tropical fruits and unconventional foods of the Andes and the rain forest of Colombia, Food Chem. 95 (2006) 644-652.

[8] Ekholm P., Reinivuo H., Mattila P., Pakkala H., Koponen J., Happonen A., Hellström J., Ovaskainen M.-L., Changes in the mineral and trace element contents of cereals, fruits and vegetables in Finland, J. Food Compost. Anal. 20 (2007) 487-495.

[9] Silva A.L.O.d., Barrocas P.R., Jacob S.d.C., Moreira J.C., Dietary intake and health effects of selected toxic elements. Braz. J. Plant Physiol. 17 (2005) 79-93.

[10] Willett W.C., Balancing life-style and genomics research for disease prevention, Science 296 (2002) 695-698.

[11] He Z.L., Yang X.E., Stoffella P.J., Trace elements in agroecosystems and impacts on the environment J. Trace Elem. Med. Biol. 19 (2005) 125-140.

[12] Gadzekpo V., Christian G., Determination of selectivity coefficients of ion-selective electrodes by a matched-potential method, Anal. Chim. Acta 164 (1984) 279-282.

[13] Welch R.M., Graham R.D., Agriculture: the real nexus for enhancing bioavailable micronutrients in food crops, J. Trace Elem. Med. Biol. 18 (2005) 299-307.

[14] Corrêa F.d.O., Souza C.A.S., Mendonça V., Carvalho J.d., Acúmulo de nutrientes em mudas de aceroleira adubadas com fósforo e zinco, Rev. Bras. Frutic. 24 (2002) 765-769.

[15] Hakala M., Lapveteläinen A., Huopalahti R., Kallio H., Tahvonen R., Effects of varieties and cultivation conditions on the composition of strawberry, J. Food Compost. Anal. 16 (2003) 67-80.

[16] Bataglia O.C., Nutrição mineral de plantas: a contribuição brasileira, O Agronômico 55 (2003) 40-43.

[17] Clark M.S., Horwath W.R., Shennan C., Scow K.M., Changes in soil chemical properties resulting from organic and low-input farming practices, Agron. J. 90 (1998) 662-671.

[18] Mäder P., Fliessbach A., Dubois D., Gunst L., Fried P., Niggli U., Soil fertility and biodiversity in organic farming, Science 296 (2002) 1694-1697.

[19] U. S. Institute of Medicine, Dietary reference intakes for vitamin C, vitamin E, selenium, and carotenoids, National Academy Press, Washington, D.C., 2000.

[20] U. S. Institute of Medicine, Dietary reference intakes for water, potassium, sodium, chloride, and sulfate, National Academy Press, Washington, D.C., 2005.
[21] U. S. Institute of Medicine, Dietary reference intakes: for calcium, phosphorus, magnesium, vitamin D, and fluoride. National Academy Press, Washington, D.C., 1997.

[22] U. S. Institute of Medicine, Dietary reference intakes for vitamin A, vitamin $\mathrm{K}$, arsenic, boron, chromium, copper, iodine, iron, manganese, molybdenum, nickel, silicon, vanadium and zinc, National Academy Press, Washington, D.C., 2001.

[23] Brasil., Ministério da Saúde (MS), Portaria SVS/MS nº27, de 13 de janeiro de 1998. Regulamento técnico referente à informação nutricional complementar (declarações relacionadas ao conteúdo de nutrientes), Diário Oficial da União, Brasília-DF, 1998.

[24] Davis D.R., Epp M.D., Riordan H.D., Changes in USDA food composition data for 43 garden crops, 1950 to 1999, J. Am. Coll. Nutr. 23 (2004) 669-682.

[25] Trewavas A., A critical assessment of organic farming-and-food assertions with particular respect to the UK and the potential environmental benefits of no-till agriculture, Crop Prot. 23 (2004) 757-781.

[26] Pussemier L., Larondelle Y., Van Peteghem C., Huyghebaert A., Chemical safety of conventionally and organically produced foodstuffs: a tentative comparison under Belgian conditions, Food Control. 17 (2006) 14-21.

[27] Caris-Veyrat C., Amiot M.-J., Tyssandier V., Grasselly D., Buret M., Mikolajczak M., Guilland J.-C., Bouteloup-Demange C., Borel P., Influence of organic versus conventional agricultural practice on the antioxidant microconstituent content of tomatoes and derived purees; consequences on antioxidant plasma status in humans, J. Agric. Food Chem. 52 (2004) 6503-6509.

[28] Brasil., Agência Nacional de Vigilância Sanitária (ANVISA), Decreto $\mathrm{n}^{\circ} 55871$, de 26 de março de 1965. Modifica o Decreto $\mathrm{n}^{\circ} 50040$, de 24 de janeiro de 1961, referente a normas reguladoras do emprego de aditivos para alimentos, alterado pelo Decreto $n^{\circ} 691$, de 13 de março de 1962, Diário Oficial da União, Brasília-DF, 1965.

[29] Soliman K., Zikovsky L., Concentrations of Al in food sold in Montreal, Canada, and its daily dietary intake, J. Radioanal. Nucl. Chem. 242 (1999) 807-809.

[30] Peris M., Micó C., Recatalá L., Sánchez R., Sánchez J., Heavy metal contents in horticultural crops of a representative area of the European Mediterranean region, Sci. Total Environ. 378 (2007) 42-48.

[31] Brasil., Ministério da Agricultura Pecuária e Abastecimento, Portaria $n^{\circ} 49$, de 25 de abril de 2005. Projeto de Instrução Normativa que aprova os limites máximos de agentes fitotóxicos, patogênicos ao homem, animais e plantas, metais pesados tóxicos, pragas e ervas daninhas admitidos nos fertilizantes, corretivos, inoculantes e biofertilizantes, Diário Oficial da União, Brasília-DF, 2005. 